\title{
Agronomic Bio fortification in Rice with Zn
}

\author{
Sabia Akhter*, Rubia Rasool, Ambreen Nabi, Vaseem Yousuf, \\ Nasir A. Dar, Khurshid Ahmad Sofi, Rafia Munshi and Mir Nadeem
}

KVK Budgam, SKUAST K, Shalimar

Srinager, $J \& K$, 191111, India

*Corresponding author

\section{Keywords}

Agronomic,

Bio fortification,

Rice, Zn deficiency

Article Info

Accepted:

24 September 2020

Available Online:

10 October 2020

\section{A B S T R A C T}

Zinc $(\mathrm{Zn})$ deficiency is a well documented public health issue and an important soil constraint to crop production. Also, there is a close geographical overlap between soil and human deficiency of $\mathrm{Zn}$ and Fe indicating a high requirement for increasing concentrations of micronutrients in food crops. Breeding new plant genotypes for high grain concentrations of $\mathrm{Zn}$ (genetic biofortification) is the most cost-effective strategy to address the problem; but, this strategy is a long-term process. A rapid approach is therefore required for biofortification of food crops with $\mathrm{Zn}$ and represents useful complementary approach to on-going breeding programs. In this regard, agronomic biofortification or fertilizer strategy (ferti-fortification) represents an effective way and rapid process for combating $\mathrm{Zn}$ malnutrition in developing countries. Ferti-fortification is the application of fertilisers to seeds, soil and/or foliage, at rates greater than those required for maximum yield, to increase the uptake of nutrients into the plants and its translocation into seeds. Zinc-enriched grains are of great importance for crop productivity resulting in better seedling vigour, denser stands and higher stress tolerance on potentially Zn-deficient soils. Soil plus foliar application of micronutrients is the best application method and foliar sprays should be done at proper stages of crop growth to increase the grain yield and micronutrient concentration in grain part. This review discusses bio-fortification and fertifortification studies of $\mathrm{Zn}$, its deficiency in human populations, public health and socioeconomic concerns and future prospects/strategies to reduce its deficiency in soil and ultimately human populations.

\section{Introduction}

In the developing world Zinc is a growing public health and socioeconomic issue (Welch and Graham 2004). Micronutrient malnutrition afflicts over three billion people worldwide and the numbers are continuously increasing. It is due to strong detrimental dietary preferences, low consumption of animal products, fruits and vegetables, intake of poor quality diets like cereals as these are inherently very low in zinc contents particularly when grown on potentially deficient soils. Several strategies have been suggested as intervention programmes for the reduction of micronutrient malnutrition in 
human populations (Maberly et al., 1994). They include food fortification as done in salt, sugar, cereals, milk and tea; dietary supplementation by use of iodized oil, vitamin A capsules and iron tablets. Other strategies are dietary diversification through consumption of red meat, liver and adequacy of vitamin $\mathrm{C}$ and biofortification through agronomic approach and Genetic approach. Agricultural strategies that are used to improve the nutritional value of crop plants are known as biofortification strategies (Cakman and Kutman, 2018). Genetic approach is a strategy that uses plant breeding techniques to produce staple food crops with higher micronutrient levels, reducing levels of anti-nutrients and increasing the levels of substances that promote nutrient absorption (Bouis, 2003). It offers a sustainable solution to malnutrition problems by exploring natural genetic variation to develop mineral-dense crop varieties (Pfeiffer and McClafferty, 2007a) and is the most cost-effective strategy to address the problem; but, this strategy is a long-term process. A rapid and complementary approach is therefore required for bio fortification of food crops with $\mathrm{Zn}$ short term. In this regard, agronomic bio fortification (fertilizer strategy) seems to be a very cost-effective, fast and practical approach to improve $\mathrm{Zn}$, concentration in cereal crops. Agronomic approaches to biofortification include Ferti-fortification (adequate fertilization, method of fertilization, time of application), FYM application, intercropping and Crop rotation. Ferti fortification is the application of fertilisers to seeds, soil and/or foliage, at rates greater than those required for maximum yield, to increase the uptake of nutrients into the plants and its translocation into seeds (Prasad, 2007).

\section{Zinc deficiency in human populations and crop production}

Zinc deficiency is a well-documented, global micronutrient deficiency problem both in human populations and in crop production. Close geographical overlapping between soil and human deficiency of $\mathrm{Zn}$, indicates a high requirement for increasing concentrations of micronutrients in food crops (Fig. 1).

It is estimated that about $50 \%$ of the cerealcultivated soils globally are deficient in plantavailable zinc, leading to reductions in crop production and also nutritional quality of the harvested grains. Zinc is an essential constituent of several enzymes like carbonic anhydrase and dehydrogenase. It also controls the synthesis of Indole acetic acid which is an important growth regulator (Graham et al., 1992). Dietary zinc deficiency is associated with severe consequences in human health, including impairments in brain function and development, weakness of the immune system to deadly infectious diseases and delays in physical development. According to a WHO report on the risk factors responsible for development of illnesses and diseases, $\mathrm{Zn}$ deficiency ranks 11th among the 20 most important factors in the world and $5^{\text {th }}$ among the 10 most important factors in developing countries. Deficiencies of $\mathrm{Zn}$ and other micronutrients in developing countries are also reported to cause great economic losses and have a considerable effect on the gross national product by decreasing productivity and increasing the health care costs (Stein, 2014). Based on a range of reports and survey studies, the average concentration of $\mathrm{Zn}$ in a whole grain of wheat in various countries is between 20 to $35 \mathrm{mg} \mathrm{kg}^{-1}$ (Rengel et al., 1999; Cakmak, 2004). The Zn concentrations reported are too low to meet daily human requirement, especially for those consuming a high proportion of cereal-based diets. For a measurable biological impact on human health, the concentration of $\mathrm{Zn}$ in whole wheat grain needs to be increased at least by approximately $10 \mathrm{mg} \mathrm{kg}^{-1}$, assuming a $400 \mathrm{~g}$ per day intake for adult woman in the countries where whole grain flour is used for making food like chapatti in India (Pfeiffer 
and McClafferty, 2007b). Generally, recommended dietary allowance for $\mathrm{Zn}$ is around $15 \mathrm{mg}$ per day (National Research Council 1989) (Table 1). Zinc content of some foods is shown in (Table 2).

Besides having inherently low levels of $\mathrm{Zn}$, wheat grain is also rich in substances limiting utilization (bioavailability) of $\mathrm{Zn}$ in the human digestive tract, such as polyphenols and phytic acid (Welch and Graham 2004). Phytic acid is the major storage compound of phosphorus in grain. By binding Zn, phytic acid reduces solubility of $\mathrm{Zn}$ in food and restricts its utilization and retention in human body. Most of the seed- $\mathrm{Zn}$ is located in the embryo and aleurone layer, whereas the endosperm is very low in $\mathrm{Zn}$ concentration (Ozturk et al., 2006). The embryo and aleurone parts are also rich in protein and phytate (Lott and Spitzer 1980; Mazzolini et al., 1985), indicating that protein and phytate in seeds could be sinks for $\mathrm{Zn}$. According to a Zn-staining study in wheat seed (Fig. 2), Zn concentrations were found to be around 150 $\mathrm{mg} \mathrm{kg}^{-1}$ in the embryo and aleurone layer and only $15 \mathrm{mg} \mathrm{kg}^{-1}$ in the endosperm (Ozturk et al., 2006).

The Zn-rich parts of wheat seed are removed during milling, thus resulting in a marked reduction in flour $\mathrm{Zn}$ concentrations. Consequently, heavy consumption of high proportion of milled wheat and other cereal products may result in reduced intake of $\mathrm{Zn}$. Enrichment of cereal grains with $\mathrm{Zn}$ is, therefore, a high priority area of research and will contribute to minimizing Zn deficiency related health problems in humans. Ccommonly used Zinc Fertilizer materials are shown in (Table 3 ).

\section{Enrichment of cereal grains with zinc through ferti-fortification}

Genetic biofortification and agronomic biofortification are two important agricultural tools to improve cereal grain $\mathrm{Zn}$ concentration (Cakmak, 2008; Pfeiffer, 2007). However, yield factor, interactions between genotype and environment, lack of sufficient genetic diversity in current cultivars for breeding program, consumer resistance and safety of genetically modified crops are the main bottlenecks of genetic biofortification (Falk, 2002; Palmgren, 2008 and Joshi, 2010). The traditional and efficient strategy of agronomic biofortification, such as $\mathrm{Zn}$ fertilization (fertifortification) is, therefore essential and rapid solution for improving $\mathrm{Zn}$ concentration in rice grain to address the ongoing human $\mathrm{Zn}$ deficiency.

Considerable progress has been made on the impact of foliar $\mathrm{Zn}$ fertilization on biofortification of $\mathrm{Zn}$ in rice grain (Fang et al., 2008, Phattarakul et al., 2012, Wissuwa et al., 2008) since it has the advantages of low application rates and avoiding $\mathrm{Zn}$ losses through soil fixation (Nasri et al., 2011). Furthermore, foliar applied $\mathrm{Zn}$ caused greater increases in brown rice $\mathrm{Zn}$ concentration than soil application (Phattarakul et al., 2012). There is evidence in literature demonstrating that foliar applied $\mathrm{Zn}$ can be absorbed by leaf epidermis, and remobilized and transferred into the rice grains through the phloem (Wu et al., 2010) and several members of the $\mathrm{Zn}$ regulated transporters regulate this process (Bashir et al., 2012). Brown rice $\mathrm{Zn}$ concentration was significantly increased by foliar Zn fertilizations (Fig. 3A).

$\mathrm{Zn}$ concentration in brown rice was increased from $30.28 \mathrm{mg} \mathrm{kg}^{-1}$ in the control to $33.75 \mathrm{mg}$ $\mathrm{kg}^{-1}$ by foliar Zn-EDTA application, to 35.07 $\mathrm{mg} \mathrm{kg} \mathrm{kg}^{-1}$ by foliar Zn-Citrate application, to $38.45 \mathrm{mg} \mathrm{kg}^{-1}$ by foliar $\mathrm{ZnSO}_{4}$ application, to $39.84 \mathrm{mg} \mathrm{kg}^{-1}$ by foliar Zn-AA application, these represented increases of $11.46 \%$, $15.81 \%, 27.26 \%$ and $31.58 \%$, respectively. $\mathrm{Zn}$ concentration in polished rice was significantly increased by foliar $\mathrm{Zn}$ fertilizations. $\mathrm{Zn}$ concentration in polished 
rice was increased from $22.92 \mathrm{mg} \mathrm{kg}^{-1}$ in the control, to $25.26 \mathrm{mg} \mathrm{kg}^{-1}$ by foliar Zn-EDTA application, to $26.09 \mathrm{mg} \mathrm{kg}^{-1}$ by foliar $\mathrm{Zn}$ Citrate application, to $28.08 \mathrm{mg} \mathrm{kg}^{-1}$ by foliar $\mathrm{ZnSO}_{4}$ application, to $28.67 \mathrm{mg} \mathrm{kg}^{-1}$ by foliar $\mathrm{Zn}$-AA application, these represented increases of $10.22 \%, 13.82 \%, 22.47 \%$ and $24.04 \%$, respectively. Thus, foliar $\mathrm{Zn}$ fertilization could increase $\mathrm{Zn}$ concentration in brown rice and polished rice depending on $\mathrm{Zn}$ form (Wei et al., 2012). Ozturk et al., (2006) studied changes in grain $\mathrm{Zn}$ concentration in wheat during the reproductive stage and found that the highest concentration of grain $\mathrm{Zn}$ occurs during the milk stage of grain development. Foliar application of $\mathrm{Zn}$ during reproductive growth seems to be more effective in increasing grain $\mathrm{Zn}$ concentration than spraying of $\mathrm{Zn}$ at earlier growth stage (Fig. 4).

In nutrient solution experiments with rice (Oryza sativa L.), post-flowering $\mathrm{Zn}$ uptake equalled or surpassed grain $\mathrm{Zn}$ content at maturity over a wide range of applied $\mathrm{Zn}$ levels (Jiang et al., 2008). Habib (2009) reported that foliar application of $(\mathrm{Fe}+\mathrm{Zn})$ at tillering and heading stage increased $\mathrm{Zn}$ concentration up to 20.27 from $12.17 \mathrm{mg} . \mathrm{kg}^{-1}$ and also Fe concentration increased compared with control (from 84.93 to $139.6 \mathrm{mg} \cdot \mathrm{kg}^{-1}$ ) (Table 4). Yilmaz, et al., 2008 found that increase in $\mathrm{Zn}$ concentration with the soil-leaf application of $\mathrm{Zn}$ were about 7 fold for shoot and 3.5 fold for grain compared to the control (Table 5). Combined application of soil and foliar $\mathrm{Zn}$ fertilizers caused more than a 3 fold increase in grain Zn (Fig. 5).

Two foliar spraying of $\mathrm{Zn}$ (@ $0.5 \%$ $\mathrm{ZnSO}_{4} \cdot 7 \mathrm{H}_{2} \mathrm{O}$ ) along with basal application (@ $20 \mathrm{~kg} \mathrm{Zn} \mathrm{ha}^{-1}$ ) increased the grain $\mathrm{Zn}$ content to the level of two to three times, while only soil applied $\mathrm{Zn}$ increased it very slightly indicating that basal application of $\mathrm{Zn}$ showed a trend to increase the grain yield, whereas, soil plus foliar application was proven to enhance the grain $\mathrm{Zn}$ content i.e. to increase the quality of the final produce (Saha et al., 2013). In rice, soil $\mathrm{Zn}$ application has been reported to increase grain yield whereas foliar-Zn application increased grain concentration of Zn (Wissuwa et al., 2008). Increased $\mathrm{Zn}$ application to soil significantly increases its concentration in the edible plant parts of staple food crops (Welch, 2002; Furlani et al., 2005).

Jat et al., (2008) reported that application of $2.0 \%$ ZEU with $\mathrm{ZnSO}_{4} .7 \mathrm{H}_{2} \mathrm{O}$ recorded significantly higher $\mathrm{Zn}$ concentrations in grain $\left(23.0 \mathrm{mg} \mathrm{kg}^{-1}\right)$ and straw (177.7 $\left.\mathrm{mg} \mathrm{kg}^{-1}\right)$ of aromatic hybrid rice followed by $2.0 \% \mathrm{ZEU}$ $(\mathrm{ZnO})$. The $\mathrm{Zn}$ concentration in rice straw was 7-8 times higher than that in grain. So $2.0 \% \mathrm{ZEU}\left(\mathrm{ZnSO}_{4} .7 \mathrm{H}_{2} \mathrm{O}\right)$ is an excellent source of $\mathrm{N}$ and $\mathrm{Zn}$ for improving productivity as well as for agronomic fertifortification of the aromatic hybrid rice (Table 6). Kanwal et al., 2010 reported that incremental addition of $\mathrm{Zn}$ to the soil significantly affected grain $\mathrm{Zn}$ accumulation in maize plants which ranged from 21.82 to $30.65 \mathrm{mg} \mathrm{kg}^{-1}$ (Fig. 6). Applying Zn-coated urea fertilizers (up to $3 \% \mathrm{Zn}$ ) increased both grain yield and grain $\mathrm{Zn}$ concentration in rice (Shivay et al., 2008; Table 7).

According to Nattinee et al., (2009) Soil Zn application did not increase grain $\mathrm{Zn}$ concentration but foliar applied $\mathrm{Zn}$ significantly and consistently increased grain $\mathrm{Zn}$ concentration from 20.5 to $45.5 \mathrm{mg}$ $\mathrm{Zn} \mathrm{kg}$ in unhusked rice and from 20.8 to $27.7 \mathrm{mg} \mathrm{Zn} \mathrm{kg}^{-1}$ in brown rice (Fig. 7). Zeidan (2001) indicated that $\mathrm{Zn}$ application significantly increased grain protein and enhanced grain $\mathrm{Zn}$ concentration, while simultaneously reduced grain $\mathrm{P}$ concentration. Lungu et al., (2010) reported the greatest increase in grain $\mathrm{Zn}$ concentration from a combination of soil $\mathrm{Zn}$ and foliar application (Table 8). 
Table.1 Recommended dietary allowance (RDA) of Zn

\begin{tabular}{|l|l|}
\hline Micronutrients & $\begin{array}{l}\text { Recommended dietary allowance } \\
\text { (mg/day) }\end{array}$ \\
\hline Zinc $(\mathbf{Z n )}$ & Infants: 5 \\
& Children : 10 \\
& Males: 15 \\
& Females: 12 \\
\hline
\end{tabular}

Prasad (2007)

Table.2 Zinc content of some foods

\begin{tabular}{|l|l|}
\hline Food item & $\mathbf{Z n}(\mathbf{m g} / \mathbf{K g})$ \\
\hline Brown rice & 18 \\
\hline Polished rice & 13 \\
\hline Wheat grain & $32-59$ \\
\hline
\end{tabular}

Prasad (2007)

Table.3 Commonly used zinc fertilizer materials

\begin{tabular}{|c|c|c|}
\hline Compound & Formula & Zinc Content (\%) \\
\hline \multicolumn{3}{|l|}{ Inorganic Compounds } \\
\hline $\begin{array}{ll}\text { Zinc } & \text { sulphate } \\
\text { monohydrate } & \end{array}$ & $\mathrm{ZnSO}_{4} \cdot \mathrm{H} 2 \mathrm{O}$ & 36 \\
\hline $\begin{array}{ll}\text { Zinc } & \text { sulphate } \\
\text { heptahydrate } & \end{array}$ & $\mathrm{ZnSO}_{4} .7 \mathrm{H} 2 \mathrm{O}$ & 22 \\
\hline Zinc oxysulphate & $\mathrm{ZnO}_{2} \mathrm{ZnSO}_{4}$ & $20-50$ \\
\hline Basic zinc sulphate & $\mathrm{ZnSO}_{4} \cdot 4 \mathrm{Zn}(\mathrm{OH})_{2}$ & 55 \\
\hline Zinc oxide & $\mathrm{ZnO}$ & $50-80$ \\
\hline Zinc carbonate & $\mathrm{ZnCO}_{3}$ & $50-56$ \\
\hline Zinc chloride & $\mathrm{ZnCl}_{2}$ & 50 \\
\hline Zinc nitrate & $\mathrm{Zn}(\mathrm{NO} 3)_{2} .3 \mathrm{H} 2 \mathrm{O}$ & 23 \\
\hline Zinc phosphate & $\mathrm{Zn}_{3}(\mathrm{PO} 4) 2$ & 50 \\
\hline Zinc frits & Fritted glass & $10-30$ \\
\hline $\begin{array}{l}\text { Ammoniated } \\
\text { sulphate solution }\end{array}$ & $\mathrm{Zn}\left(\mathrm{NH}_{3}\right) 4 \mathrm{SO} 4$ & 10 \\
\hline \multicolumn{3}{|l|}{ Organic Compounds } \\
\hline Disodium zinc EDTA & $\mathrm{Na}_{2} \mathrm{ZnEDTA}$ & $8-14$ \\
\hline Sodium zinc HEDTA & NaZnHEDTA & $6-10$ \\
\hline Sodium zinc EDTA & NaZnEDTA & $9-13$ \\
\hline Zinc polyflavonoid & - & $5-10$ \\
\hline Zinc lignosulphonate & - & $5-8$ \\
\hline
\end{tabular}


Table.4 Effect of foliar application of $\mathrm{Zn}$ on wheat yield $\left(\mathrm{kg} \mathrm{ha}^{-1}\right)$, seed- $\mathrm{Zn}$ and Fe Concentration $\left(\mathrm{mg} \mathrm{kg}^{-1}\right)$

\begin{tabular}{|l|l|l|}
\hline TreatmentlAdjective & Yield \pm SE & $\mathbf{Z n} \pm$ SE \\
\hline Fe & $8185 \pm 93.853$ & $22.6 \pm 1.493$ \\
\hline $\mathbf{Z n}$ & $7919 \pm 67.3$ & $50.9 \pm 1.114$ \\
\hline Fe+Zn & $8954 \pm 74.638$ & $20.27 \pm 1.291$ \\
\hline Control & $7665 \pm 97.994$ & $12.17 \pm 1.317$ \\
\hline LSD (=0.01) & 414.7 & 3.85 \\
\hline
\end{tabular}

Table.5 Effect of different $\mathrm{Zn}$ application methods on $\mathrm{Zn}$ concentration in wheat

\begin{tabular}{|l|c|c|}
\hline \multirow{2}{*}{$\begin{array}{l}\text { Zn application } \\
\text { methods }\end{array}$} & $\begin{array}{c}|c| \\
\text { Cn concentration (mg/kg) }\end{array}$ \\
\cline { 2 - 3 } & Whole shoot & Grain \\
\hline Control & 10 & 10 \\
\hline Seed coating & 12 & 10 \\
\hline Foliar & 19 & 18 \\
\hline Soil + Foliar & 60 & 27 \\
\hline
\end{tabular}

(1)control (no $\mathrm{Zn}$ application); (2) $23 \mathrm{~kg} \mathrm{Zn/ha} \mathrm{as} \mathrm{broadcast} \mathrm{to} \mathrm{soil;} \mathrm{(3)} \mathrm{seed} \mathrm{coating} \mathrm{(1L} \mathrm{30 \%} \mathrm{ZnSO4} \mathrm{sprayed} \mathrm{on} \mathrm{to}$ $10 \mathrm{~kg}$ seeds and then the seeds dried and sown); (4) foliar application (440 g Zn/ha as ZnSO4 in $450 \mathrm{l}$ at tillering and stem elongation); (5) combination of the methods 2 and 4

Table.6 Effect of $\mathrm{Zn}$ fertilization on yield and $\mathrm{Zn}$ concentrations of aromatic hybrid rice

\begin{tabular}{|c|c|c|c|c|}
\hline Treatments & $\begin{array}{ll}\text { Zn } & \text { applied } \\
(\mathrm{kg} / \mathrm{ha}) & \end{array}$ & Grain yield (t/ha) & $\begin{array}{l}\text { Grain Zn conc. } \\
(\mathrm{mg} / \mathrm{kg})\end{array}$ & $\begin{array}{l}\text { Straw Zn } \\
\text { conc. } \\
(\mathrm{mg} / \mathrm{kg})\end{array}$ \\
\hline $\begin{array}{l}\text { Absolute Control (No N \& } \\
\text { No Zn) }\end{array}$ & - & 5.03 & 15.0 & 125.2 \\
\hline Control (Only N) & - & 6.74 & 17.0 & 144.0 \\
\hline $2.0 \% \mathrm{ZEU}\left(\mathrm{ZnSO}_{4} .7 \mathrm{H}_{2} \mathrm{O}\right)$ & 5.0 & 7.53 & 23.0 & 177.7 \\
\hline 2.0\% ZEU (ZnO) & 5.0 & 7.30 & 20.0 & 164.6 \\
\hline $5.0 \mathrm{~kg} \mathrm{Zn} / \mathrm{ha}\left(\mathrm{ZnSO}_{4} .7 \mathrm{H}_{2} \mathrm{O}\right)$ & 5.0 & 7.17 & 21.1 & 161.3. \\
\hline $5.0 \mathrm{~kg} \mathrm{Zn/ha}(\mathrm{ZnO})$ & 5.0 & 7.04 & 19.2 & 151.8 \\
\hline CMCU & - & 6.80 & 17.0 & 143.1 \\
\hline SEm \pm & - & 0.12 & 0.08 & 0.56 \\
\hline $\mathrm{CD}(\mathbf{P}=\mathbf{0 . 0 5})$ & - & 0.33 & 0.24 & 1.60 \\
\hline
\end{tabular}

ZEU*, Zn- enriched urea; $\mathbf{C M C U * * , ~ C o a t i n g ~ m a t e r i a l ~ c o a t e d ~ u r e a ~}$ 
Table.7 Effect of Zn-enriched urea (ZEU) (up to $3 \% \mathrm{Zn}$ in urea) on grain yield and grain $\mathrm{Zn}$ concentrations of aromatic rice grown in India. Data show average values of 2-year field trials

\begin{tabular}{|l|l|l|}
\hline Treatments & Grain Yield (ton ha $\left.\mathbf{~}^{-\mathbf{1}}\right)$ & $\begin{array}{l}\text { Zn Concentration } \\
\left(\mathbf{m g ~ k g} \mathbf{~ k W}^{-\mathbf{1}} \mathbf{D W}\right.\end{array}$ \\
\hline Prilled Urea & 3,87 & 27 \\
\hline $\mathbf{0 . 5 \%}$ ZEU & 4,23 & 29 \\
\hline $\mathbf{1 . 0 \%}$ & 4,39 & 33 \\
\hline $\mathbf{2 . 0 \%}$ & 4,60 & 39 \\
\hline $\mathbf{3 . 0 \%}$ & 4,76 & 42 \\
\hline
\end{tabular}

Table.8 Effect of soil and foliar application of zinc on grain zinc concentration of wheat

\begin{tabular}{|l|l|}
\hline Treatment & Grain $\mathbf{Z n , ~} \mathbf{m g ~ k g}^{\mathbf{1}}$ \\
\hline Control & $23.5 \pm 2.1$ \\
\hline NPK + Urea & $20.8 \pm 2.2$ \\
\hline Soil Zn & $23.8 \pm 1.1$ \\
\hline NPK + Urea + Soil Zn & $24.2 \pm 3.2$ \\
\hline Soil Zn + 2X Foliar Zn & $43.0 \pm 5.6$ \\
\hline NPK+ Urea + Soil Zn +2X Foliar Zn & $46.4 \pm 4.7$ \\
\hline
\end{tabular}

Table.9 The concentration of $\mathrm{Zn}$ in growth media and in plants $\left(\mathrm{mg} \mathrm{x} \mathrm{kg}^{-1}\right)$ grown on media consisting of soil control, FA1, FA2, BA or FA2+BA

\begin{tabular}{|l|l|l|l|l|l|l|}
\hline Media & $\begin{array}{l}\text { Zn con.in } \\
\text { Growth medium }\end{array}$ & Barley & Oats & Rye & Triticale & $\begin{array}{l}\text { Winter } \\
\text { wheat }\end{array}$ \\
\hline Soil & $15.2 \pm 0.4 \mathrm{a}$ & $17.5 \pm 3.3 \mathrm{a}$ & $33.4 \pm 6.2 \mathrm{a}$ & $27.0 \pm 4.1 \mathrm{a}$ & $31.1 \pm 3.4 \mathrm{a}$ & $18.0 \pm 2.4 \mathrm{a}$ \\
\hline FA1 & $51.1 \pm 7.4$ & $92.8 \pm 19.1 \mathrm{~b}$ & $\mathbf{1 3 3 . 4 \pm 2 2 . 2 b}$ & $87.8 \pm 8.9 \mathrm{~b}$ & $78.0 \pm 7.9 \mathrm{~b}$ & $\mathbf{1 9 2 . 2 \pm 2 9 . 8 b}$ \\
\hline FA2 & $46.9 \pm 8.3 \mathrm{~b}$ & $89.4 \pm 14.0 \mathrm{~b}$ & $134.2 \pm 25.5 \mathrm{~b}$ & $93.1 \pm 9.4 \mathrm{~b}$ & $74.2 \pm 8.1 \mathrm{~b}$ & $167.6 \pm 24.2 \mathrm{~b}$ \\
\hline BA & $21.7 \pm 3.7 \mathrm{c}$ & $51.4 \pm 7.7 \mathrm{c}$ & $93.6 \pm 17.0 \mathrm{c}$ & $53.3 \pm 5.2 \mathrm{c}$ & $53.8 \pm 6.8 \mathrm{c}$ & $76.5 \pm 16.0 \mathrm{c}$ \\
\hline FA2+BA & $31.1 \pm 5.7 \mathrm{c}$ & $50.2 \pm 6.7 \mathrm{c}$ & $84.8 \pm 19.3 \mathrm{~d}$ & $60.8 \pm 7.7 \mathrm{c}$ & $47.9 \pm 5.1 \mathrm{c}$ & $73.6 \pm 17.3 \mathrm{c}$ \\
\hline $\begin{array}{l}\text { Soil as a control } \\
\text { FA1 (Fly ash) from lignite coal } \\
\text { FA2 from semi-bituminous coal } \\
\text { BA (bottom ash) from semi-bituminous coal } \\
\text { FA/BA (1:1 weight based) from semi-bituminous coal }\end{array}$ & & & & & & \\
\hline
\end{tabular}


Table.10 Effect of zinc, iron and manganese on mineral composition of rice KS- 282

\begin{tabular}{|l|l|}
\hline Treatment & $\mathbf{Z n}(\mathbf{m g} / \mathbf{k g})$ \\
\hline Control & $27.10 \mathrm{e}$ \\
\hline $\mathbf{N P K}$ & $28.00 \mathrm{e}$ \\
\hline $\mathbf{N P K}+\mathbf{F e}$ & $25.23 \mathrm{f}$ \\
\hline $\mathbf{N P K}+\mathbf{M n}$ & $26.60 \mathrm{ef}$ \\
\hline $\mathbf{N P K}+\mathbf{F e}+\mathbf{Z n}_{\mathbf{1}}$ & $36.97 \mathrm{~d}$ \\
\hline $\mathbf{N P K}+\mathbf{F e}+\mathbf{Z n} \mathbf{n}_{\mathbf{2}}$ & $44.47 \mathrm{~b}$ \\
\hline $\mathbf{N P K}+\mathbf{M n}+\mathbf{Z n}_{\mathbf{1}}$ & $39.17 \mathrm{c}$ \\
\hline $\mathbf{N P K}+\mathbf{M n}+\mathbf{Z n}_{\mathbf{2}}$ & $46.53 \mathrm{a}$ \\
\hline
\end{tabular}

Means sharing the same letter (s) do not significantly at $\mathrm{P}=0.05$ level of probability (DMR test) $\mathrm{NPK}=100: 50: 50(\mathrm{mg} / \mathrm{kg}$ soil $)$

Fe:Mn: $\mathrm{Zn}_{1}: \mathrm{Zn}_{2}=10: 10: 5: 10(\mathrm{mg} / \mathrm{kg}$ soil $)$

Design $=$ RBD

Soil - Sandy clay loam

Fig.1

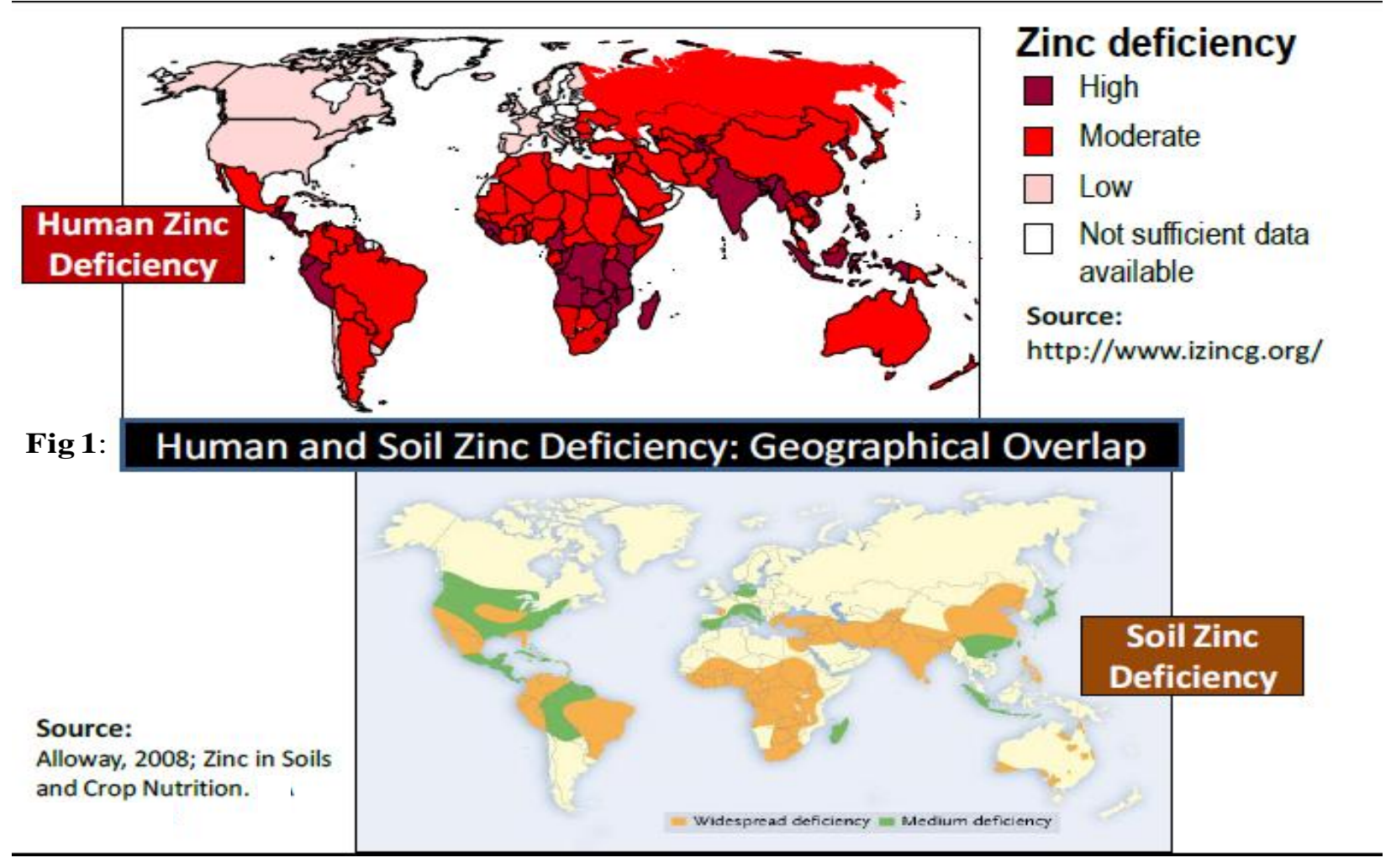


Fig.2 Diphenyl thiocarbazone (DTZ) staining a wheat seed. When reacting with Zn, DTZ forms a red DTZ-complex which indicates localization of Zn (Ozturk et al., 2006)

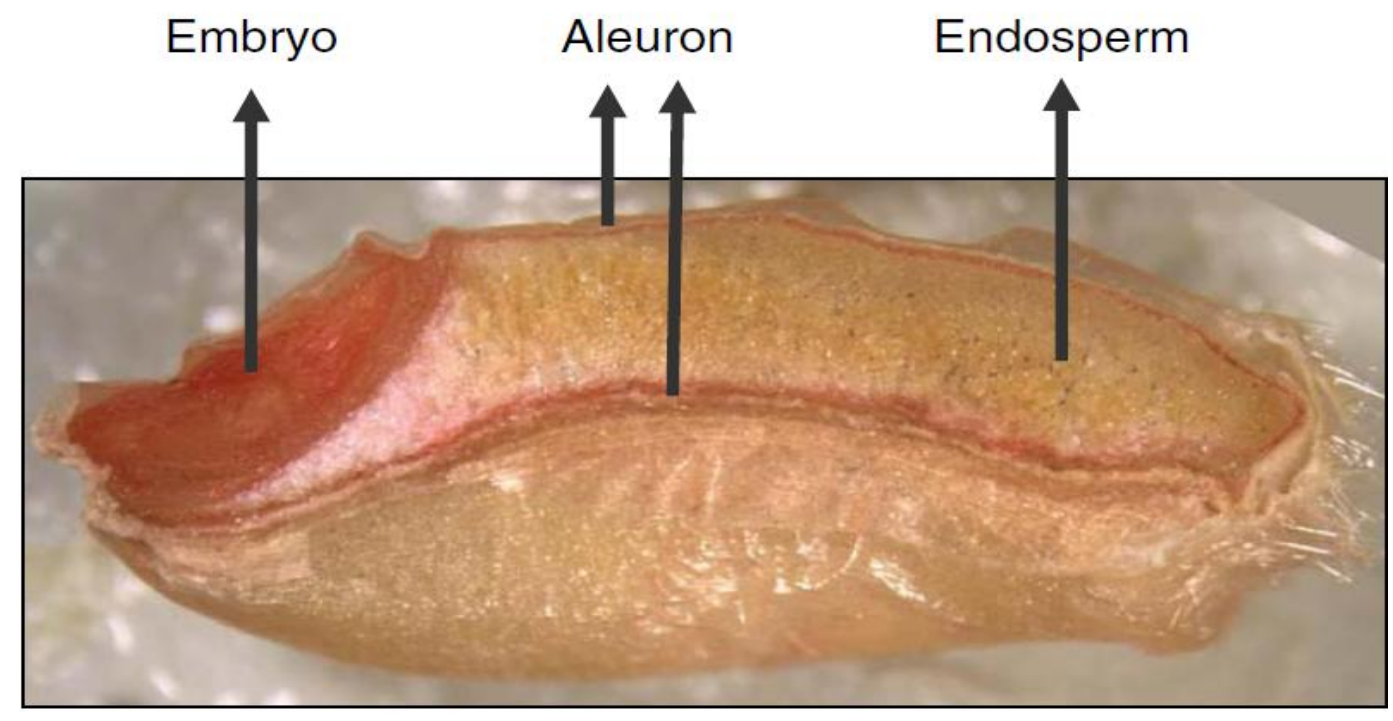

DTZ staining at increasing $\mathrm{Zn}$ concentrations, $\mathrm{mg} \mathrm{kg}^{-1}$

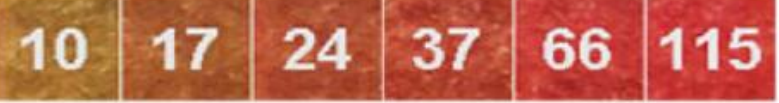

Fig.3 Effect of different forms of foliar $\mathrm{Zn}$ fertilization on $\mathrm{Zn}$ concentration in rice grain. (A) $\mathrm{Zn}$ concentration in brown rice. (B) $\mathrm{Zn}$ concentration in polished rice

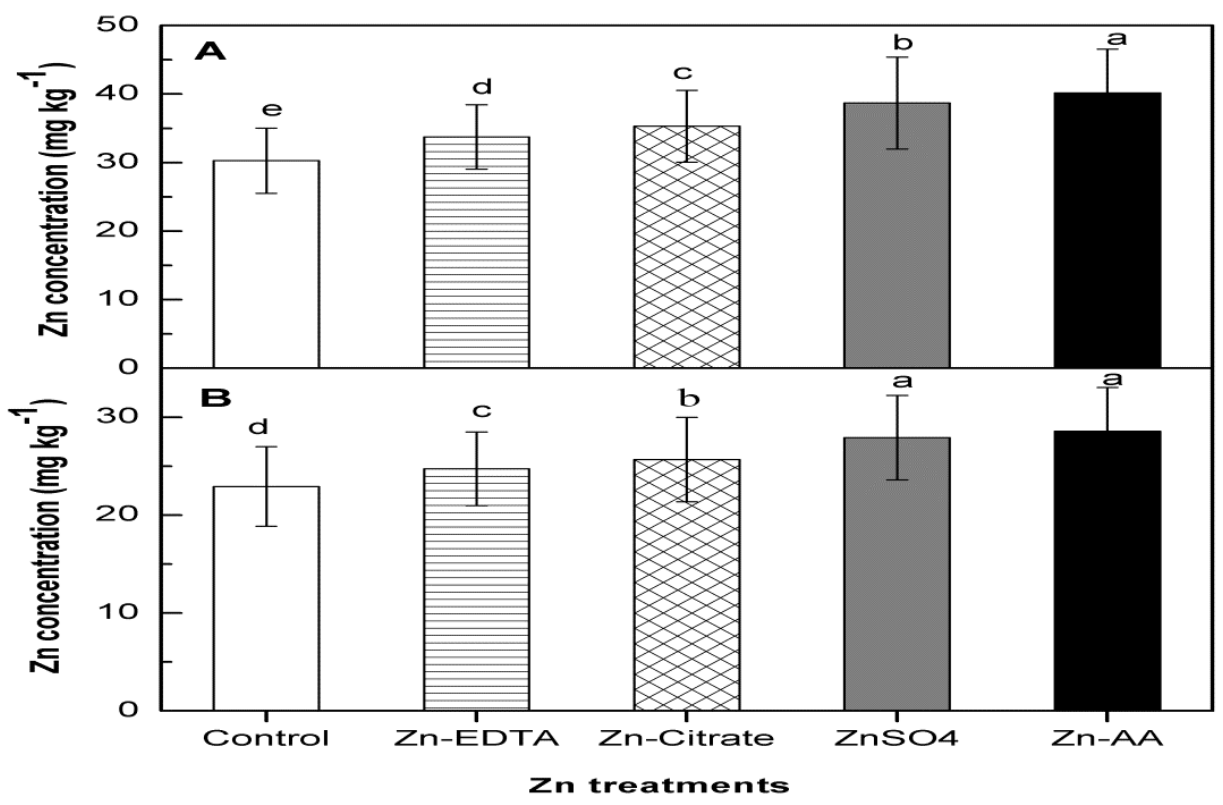


Fig.4 Effect of time of foliar application of $\mathrm{Zn}$ on grain $\mathrm{Zn}$ concentration in wheat

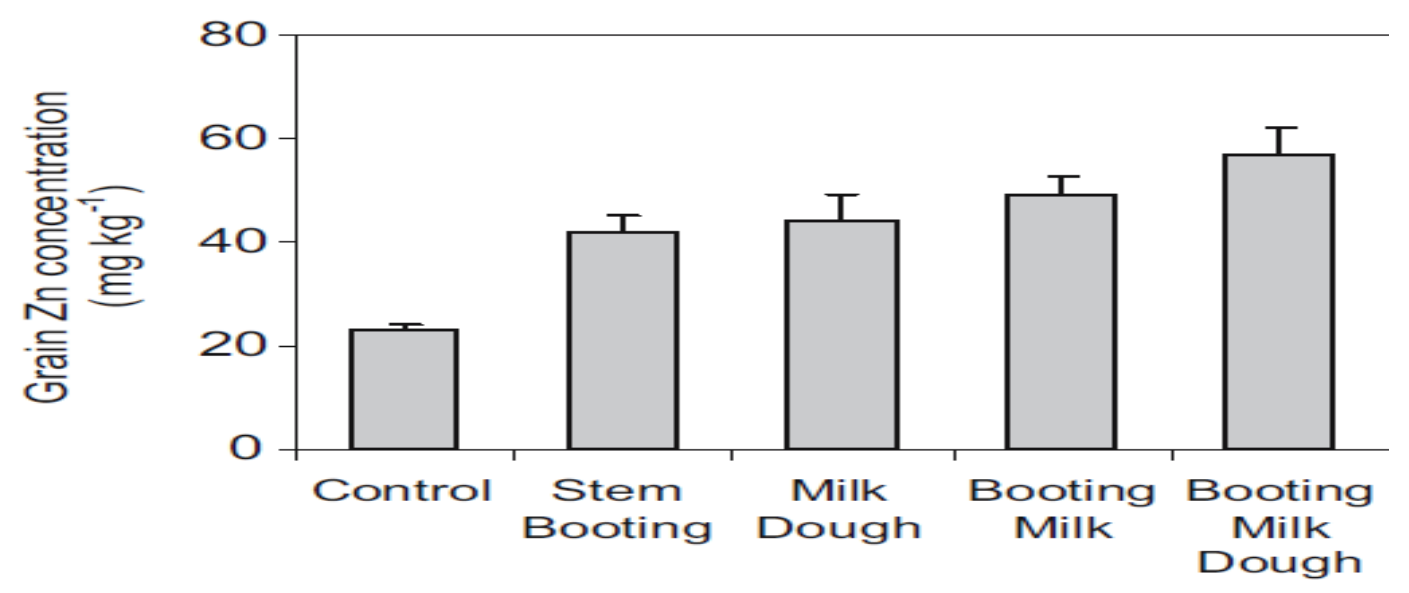

Fig.5 Enrichment of durum wheat grain with Zn applied through soil and foliar spray
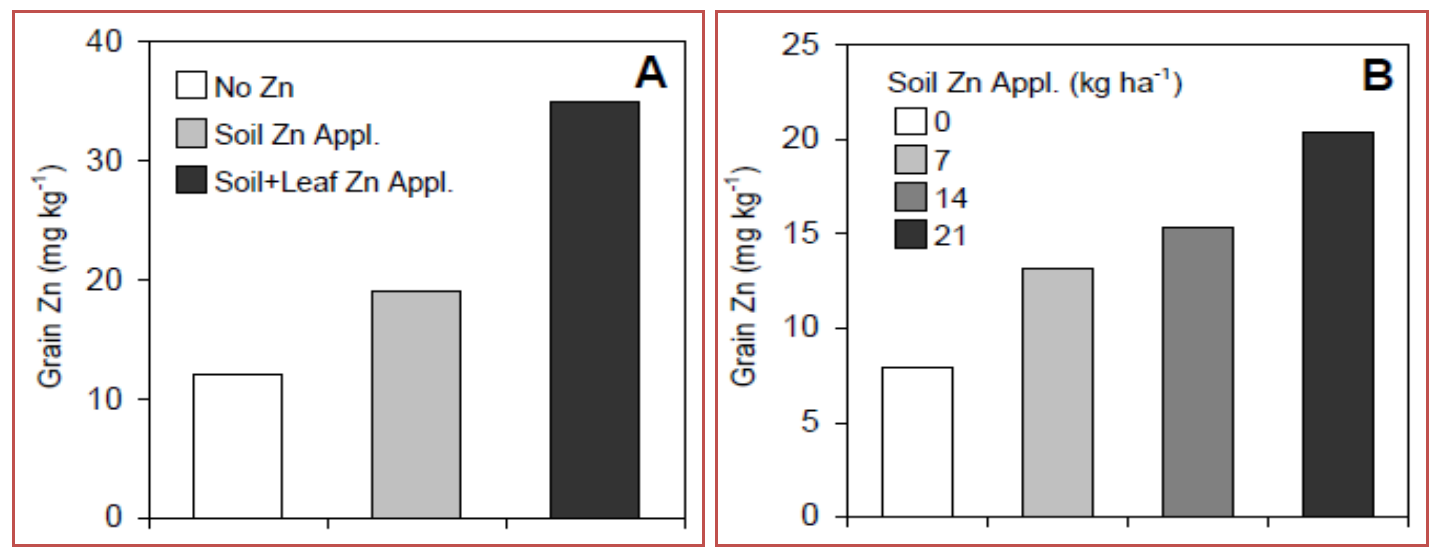

Fig.6 Grain Zn concentration of maize hybrid (FHY-421) and variety (Golden) at different rates of $\mathrm{Zn}$ application

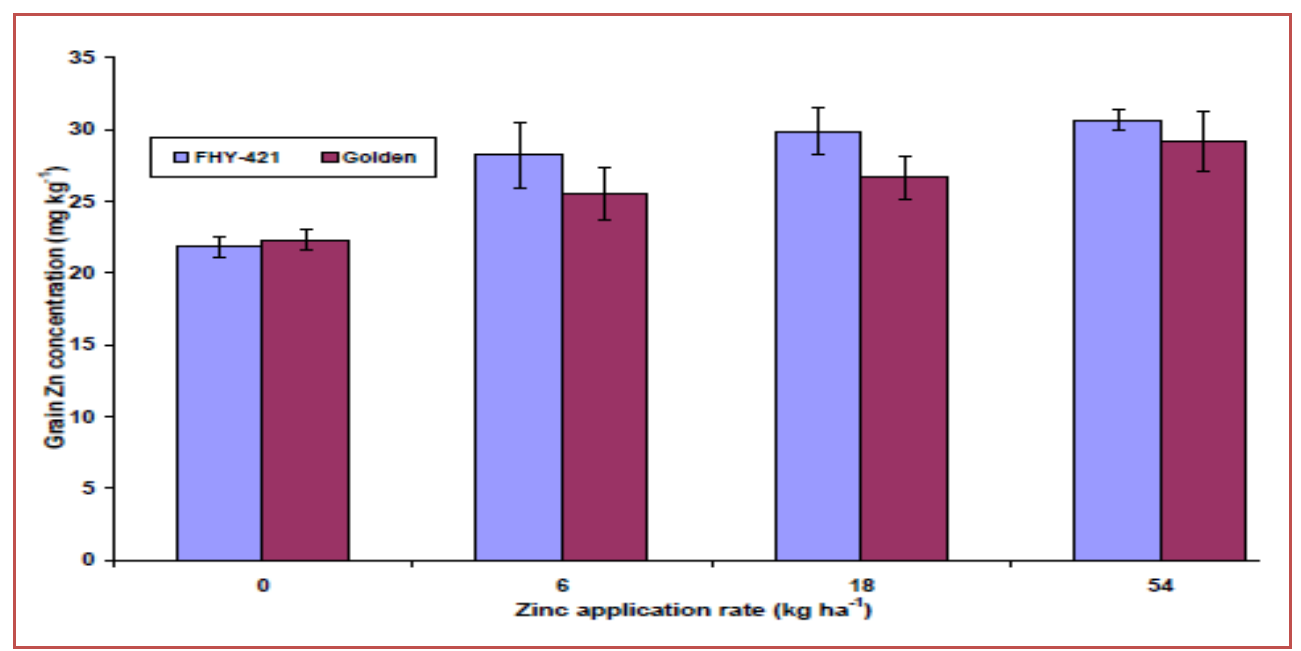


Fig.7 Concentration of $\mathrm{Zn}$ in rice seeds at 4 farmer's locations in Thailand
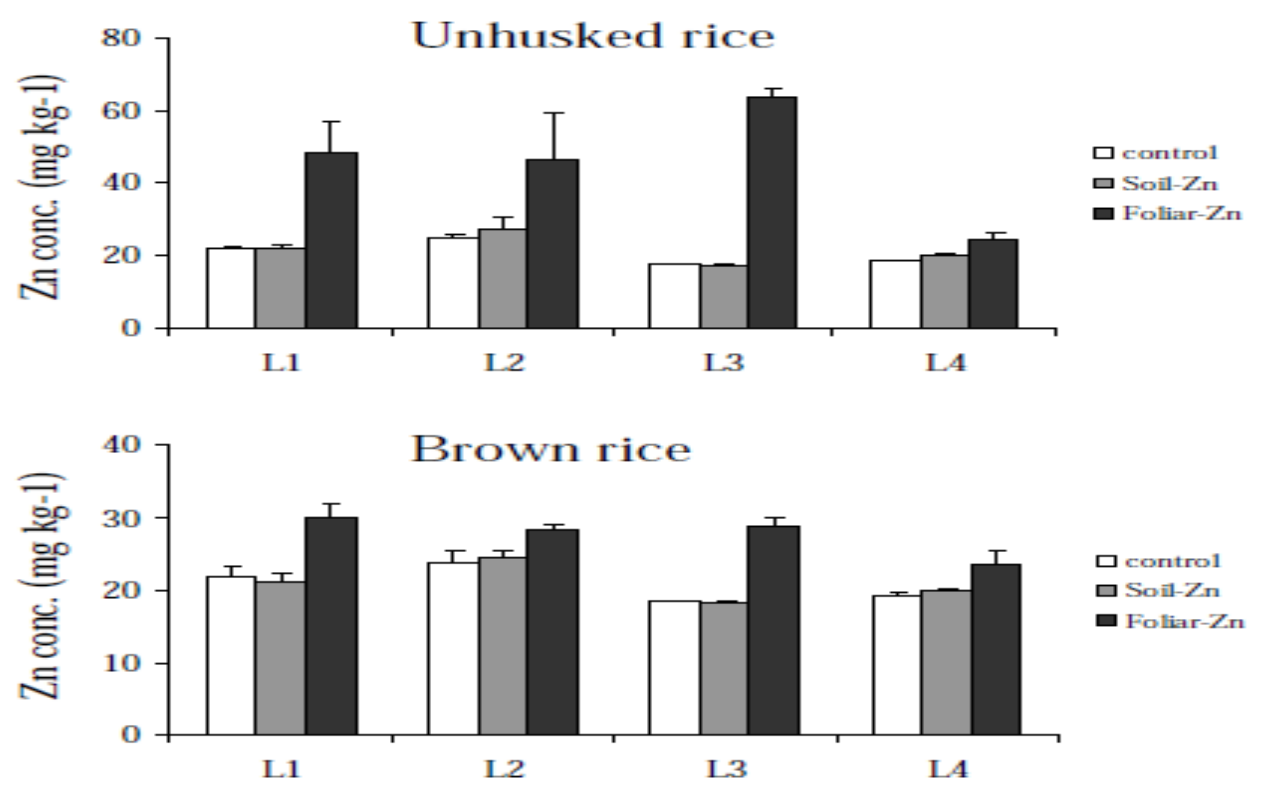

Fig.9 Agronomic and human nutritional benefits resulting from use of $\mathrm{Zn}$ enriched seeds

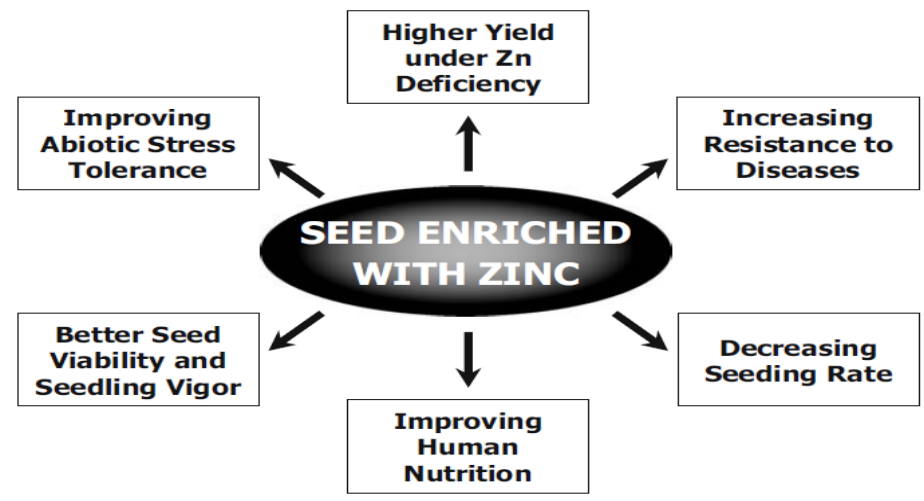

Zn fertilization significantly increased $\mathrm{Zn}$ density in polished rice, with a more pronounced effect of $\mathrm{ZnSO}_{4}$ being observed as compared with Zn-EDTA, especially under an alternate wetting and drying (AWD) regime (Fig. 8). Bilski et al., (2012) reported significant increase of $\mathrm{Zn}$ accumulation in plants grown on coal ashes and suggests that these coal combustion residues might be treated as $\mathrm{Zn}$ fertilizers especially desirable in various developing countries (e.g. in Africa) where the farmers cannot afford application of mineral fertilizers (Table 9).
Abid et al., (2001) reported highest $\mathrm{Zn}$ and $\mathrm{Mn}$ concentration in grain with $\mathrm{NPK}+\mathrm{Mn}+\mathrm{Zn}_{2}$ and $\mathrm{NPK}+\mathrm{Mn}+\mathrm{Zn}_{1}$ respectively. Both these treatments differed significantly with all other treatment, was probably due to the more balanced nutrient ratio (Table 10).

Hussain et al., 2014 also reported highest zinc content in brown rice with the application of EDTA-chelated zinc $(53.20 \mathrm{mg} / \mathrm{kg})$ followed by zinc FYM incubated (49.55 $\mathrm{mg} / \mathrm{kg}$ ), zinc sulphate $(46.40 \mathrm{mg} / \mathrm{kg})$ and control (30.04 
$\mathrm{mg} / \mathrm{kg}$ ). Increasing grain $\mathrm{Zn}$ by soil and/or foliar applications also provides additional positive impacts in terms of seed vitality and seedling vigor. Priming seeds in $\mathrm{Zn}$ containing solutions is an alternative way to increase seed $\mathrm{Zn}$ prior to sowing. High seed $\mathrm{Zn}$ concentrations ensure good root growth and contribute to better protection against abiotic and biotic stress like soil borne pathogens (Fig. 9) (Cakmak, 2012).

In conclusion, all of the approaches of fortification in general and biofortification in particular are complementary to each other and should go hand in hand to alleviate the major concern of under nutrition. Fertifortification can be a rapid solution to enrich the cereals. Seed biofortification by foliar feeding is more excellent to increase the grain yield and micronutrient concentration in grain part and has low cost as compared to other chemical methods. However, foliar sprays should be done at proper stages of crop growth. Priming seeds in $\mathrm{Zn}$-containing solutions is an alternative way to increase seed $\mathrm{Zn}$ prior to sowing. High seed $\mathrm{Zn}$ concentrations ensure good root growth and contribute to better protection against abiotic and biotic stress like soil borne pathogens. Seedlings grown on coal ash based media also showed hyper accumulation of $\mathrm{Zn}$ as compared to plants grown on normal soil thus coal combustion residues can be treated $\mathrm{Zn}$ fertilizers especially desirable in various developing countries. Moreover, intercropping and crop rotation systems also contribute to grain $\mathrm{Zn}$ concentrations and the combined applications of $\mathrm{Zn}$ fertilizers together with organic materials (like farmyard manure and green manures) are effective in facilitating $\mathrm{Zn}$ uptake by roots and correcting $\mathrm{Zn}$ deficiency. There are also promising cultivars for higher accumulation of Zinc. Agronomic experiments need to be planned and conducted for developing micronutrient fertilizer doses, methods and timings for their application for increasing not only yield but also the concentration of micronutrient in grains.

\section{References}

Abid, M., Ahmad, N., Jahangir, M., and Ahmad, I. 2001. Effect of zinc, iron and manganese on growth and yield of rice (Oryza sativa L.). Pakistan Journal of Agricultural Sciences 39(3): 178-180.

Alloway, B., J. 2008. Soil factors associated with zinc deficiency in crops and humans. Environmental Geochemistry and Health 31(5): 537-548.

Bilski, J., Jacob, D., Soumaila, F., Kraft, C. and Farnsworth, A. 2012. Agronomic Biofortification of Cereal Crop Plants with $\mathrm{Fe}, \mathrm{Zn}$ and Se by the Utilization of Coal Fly Ash as Plant Growth Media. Advances in Bioresearch 3(4): 130136.

Bouis, H., E. 2003. Micronutrient fortification of plants through plant breeding: can it improve nutrition in man at low cost. Proceedings of the Nutrition Society 62: 403-411.

Cakmak, I. and Kutman, U. B. 2018 Agronomic biofortification of cereals with zinc: a review. European Journal of Soil Science 69, 172-180

Cakmak, I. 2004. Identification and correction of widespread zinc deficiency in Turkey, A success story. IFS Proceedings No. 552, International Fertiliser Society, New York. UK, pp $1-28$.

Cakmak, I. 2012. Harvest Plus zinc fertilizer Project: Harvest Zinc. Better Crops 96: 17-19.

Falk, M. C., Chassy, B. M., Harlander, S. K., Hoban, T. J., McGloughlin, M. N. 2002. Food biotechnology: Benefits and concerns. Journal of Nutrition 132: 1384-1390.

Fang, Y., Wang, L., Xin, Z., Zhao, L., An X, 
2008. Effect of foliar application of zinc, selenium, and iron fertilizers on nutrients concentration and yield of rice grain in China. Journal of Agricultural Food Chemistry 56: 2079-2084.

Furlani, A. M. C., Furlani, P. R., Meda, A. R. and Durate, A. P. 2005. Efficiency of maize cultivars for zinc uptake and use. Science of Agriculture 62: 264-273.

Graham, R. D., Ascher, Hynes, S. C. 1992. Selecting zinc-efficient cereal genotypes for soils of low zinc status. Plant and Soil 146: 241-250.

Habib, M. 2009. Effect of foliar application of $\mathrm{Zn}$ and $\mathrm{Fe}$ on wheat yield and quality. African Journal of Biotechnol 8: 67956798.

Hussain, T., Bhat, M. A., Hussain, A. and Ganai, M. A. 2014. Agronomic biofortification of rice with organic Zinc under Kashmir valley conditions. Souvenir and abstracts, $3^{\text {rd }}$ Jammu and Kashmir Agricultural science congress

Jat, S. L., Shivay, Y. S. And Parihar, C. M. 2008. Zinc Fertilization for Improving Productivity and Zinc Concentration in Aromatic Hybrid Rice (Oryza sativa L.). http://www.researchgate.net/ publication/257917413

Jiang, W., Struik, P. C., Vankeulen, H., Zhao, M., Jin, L. N. and Stomph, T. J. 2008. Does increased zinc uptake enhance grain zinc mass concentration in rice. Annals of Applied Biology 153:135 147.

Joshi, A., Crossa, J., Arun, B., Chand, R. and Trethowan, R. 2010. Genotype $\times$ environment interaction for zinc and iron concentration of wheat grain in eastern Gangetic plains of India. Field Crops Research 116: 268-277.

Kanwal, S., Rahmatullah, M. A,, Maqsood and Bakhat, H. F. S. G. 2009. Zinc requirement of maize hybrids and indigenous varieties on Udic Haplustalf. Journal of Plant Nutrition 32:470-478.
Lott, J. N. A. and Spitzer, E. 1980. X-ray analysis studies of elements stored in protein body globoid crystals of Triticum grains. Plant Physiology 66: 27-28.

Lungu, O. I., Simunji, S. and Cakmak, I. 2011. Effects of Soil and Foliar Applications of Zinc on Grain Zinc Concentrations of Maize, Sorghum and Wheat in Zambia. International Sorghum and Millet Collaborative Research Support Program (INTSORMIL CRSP).

Maberly, G. F., Trowbridge, F. L., Yip, R., Sullivan, K. M. and West, C. E. 1994. Programs against micronutrient malnutrition; Ending hidden hunger. Annual Revision of Nutrition 15: 277301.

Mazzolini, A. P., Pallaghy, C. K., Legge, G. J. F. 1985. Quantitative microanalysis of $\mathrm{Mn}, \mathrm{Zn}$ and other elements in mature wheat seed. New Phytology 100: 483509.

Nattinee, P., Ismail, C., Panomwan, B., Jumniun W, Benjavan R 2009. The Proceedings of the International Plant Nutrition Colloquium XVI.

Ozturk, L., Yazici, M. A., Yucel, C., Torun, A., Cekic, C., Bagci, A., Ozkan, H., Braun, H. J., Sayers, Z. and Cakmak, I. 2006. Concentration and localization of zinc during seed development and germination in wheat. Physiologia plantarum 128(1): 144-152.

Palmgren, M. G., Clemens, S., Williams, L. E., Krämer, U. and Borg, S. 2008. Zinc biofortification of cereals: problems and solutions. Trends in Plant Science 13: 464-473.

Pfeiffer, W. H., McClafferty, B. 2007a. Harvest Plus: Breeding crops for better nutrition. Crop Science 47: 88-105.

Pfeiffer, W. H. and McClafferty, B. 2007b. Biofortification: Breeding Micronutrient-Dense Crops. In: Kang 
MS (Ed) Breeding major food staples. Blackwell Science Ltd (in press).

Phattarakul, N., Rerkasem, B., Li, L., Wu, L. and Zou. 2012. Biofortification of rice grain with zinc through zinc fertilization in different countries. Plant and Soil 361(1): 131-141.

Prasad, A. S. 2007. Zinc: Mechanisms of host defense. Journal of Nutrition 137:13451349

Rengel, Z., Batten, G. D. and Crowley, D. E. 1999. Agronomic approaches for improving the micronutrient density in edible portions of field crops. Field Crops Research 60: 27-40.

Saha, B., Saha, S., Roy, P. D. and Hazra, G. C. and Das, A. 2013. Zinc fertilization effects on agro morphological and quality parameters of commonly grown rice. Saarc journal of agriculture 11(1): 105-120.

Shivay, Y. S., Kumar, D. and Prasad, R. 2008. Effect of zinc-enriched urea on productivity, zinc uptake and efficiency of an aromatic rice-wheat cropping system. Nutrient Cycling in Agroecosystems 81:229-243.

Stein, A.J. 2014. Rethinking the measurement of under nutrition in a broader health context. Global Food Security, 3, 193199.

Wei Y, Shohag M J I, Yang X 2012. Bio fortification and Bioavailability of Rice Grain Zinc as Affected by Different Forms of Foliar Zinc Fertilization. plos one e45428.

\section{How to cite this article:}

Sabia Akhter, Rubia Rasool, Ambreen Nabi, Vaseem Yousuf, Nasir A. Dar and Khurshid Ahmad Sofi, Rafia Munshi and Mir Nadeem. 2020. Agronomic Bio fortification in Rice with Zn. Int.J.Curr.Microbiol.App.Sci. 9(10): 2995-3008. doi: https://doi.org/10.20546/ijcmas.2020.910.361 